\title{
Settler Colonial Strategies and Indigenous Resistance on the Great Lakes Lumber Frontier
}

Theodore Karamanski

Loyola University Chicago, tkarama@luc.edu

Follow this and additional works at: https://ecommons.luc.edu/history_facpubs

Part of the Public History Commons, and the United States History Commons

\section{Author Manuscript}

This is a pre-publication author manuscript of the final, published article.

\section{Recommended Citation}

Karamanski, Theodore. Settler Colonial Strategies and Indigenous Resistance on the Great Lakes Lumber Frontier. Middle West Review, 2, 2: 27-51, 2016. Retrieved from Loyola eCommons, History: Faculty Publications and Other Works, http://dx.doi.org/10.1353/mwr.2016.0007

This Book Review is brought to you for free and open access by the Faculty Publications and Other Works by Department at Loyola eCommons. It has been accepted for inclusion in History: Faculty Publications and Other Works by an authorized administrator of Loyola eCommons. For more information, please contact ecommons@luc.edu.

\section{(c) $(\$)$}

This work is licensed under a Creative Commons Attribution-Noncommercial-No Derivative Works 3.0 License. (C) University of Nebraska Press 2016 
Settler Colonial Strategies and Indigenous Resistance on the Great Lakes Lumber Frontier Theodore J. Karamanski

\section{$\underline{\text { Introduction }}$}

The geographic and economic setting of the nineteenth century Upper Great Lakes region created unique challenges to American settler colonialism and theirencounters with the Iindigenous people of this land of lakes and forests.- Many Anishinaabeg bands responded creatively through the use of Christianity, education, and American law in an attempt to fortify their presence in the region. -European_-Americans, who sought to appropriate the wealth of the Upper Midwest's vast stands of hardwood and pine forests, only seldom needed to resort to guns to take control of the land.-_Instead of a war of conquest they entangled Anishinaabeg property owners in a bewildering legal and extra-legal thicket that facilitated the plunder of the region's most marketable resource. The initial phase of pine logging laid waste to Anishinaabeg property rights but left the indigenous population remaining on their traditional lands. The ill_treatment of Anishinaabeg landowners should have been a warning signal to policy makers in the 1880s seeking to reform national Indian policy through severalty.

In his 2012 study of Great Lakes Indian history in the colonial and early national periods, historian Michael Witgen emphasizes the shared transregional society shared by the Anishinaabeg while at the same time documenting the "flexibility" and autonomy of action reserved to local bands.-_This essay is concerned with the indigenous response to the lumber frontier's variation of settler colonialism in the Upper Great Lakes region__-the heartland of the Anishinaabeg.-_The bulk of the essay, however, is anchored in northern Lower Michigan with some inclusion of examples from northern Wisconsin and Minnesota.-_The Odawa, Ojibwe, and Potawatomi in Lower Michigan—sometimes known as the Three Fires Confederacy and who all embraced the native name Anishinaabeg — did not respond to the intrusion of lumbering in the
Formatted: Font: Not Bold

Formatted: Left, Space After: $0 \mathrm{pt}$

Formatted: Font: Not Bold

Formatted: Space After: $0 \mathrm{pt}$ 
same way as bands in other parts of the region. Yet the impact of the logging frontier on the indigenous people was, with rare exceptions, strikingly similar. $\frac{1}{4}$

\section{In the Wake of the "Middle Ground"}

What Richard White famously dubbed a "middle ground” of cooperation and cultural exchange . that marked the Great Lakes frontier in the seventeenth and eighteenth centuries endured after the conclusion of the second war with Great Britain.--_The cultural forms and economic relations of that earlier period of French and British regimes in the region only slowly waned over several decades under American suzerainty. ${ }^{2}$-_The latent military power of the indigenous people of the Great Lakes region together with the lingering possibility of their receiving support from British Canada inclined American officials and pioneer traders to follow for a time the previously

\footnotetext{
${ }_{1}^{1}$ Michael Witgen, Infinity, of, Nations: How ,The, Native,New, World, Shaped, Early, North, America (New YorkPhiladelphia: University of Pennsylvania Press, 2012), p-19. Each of the tribal groupings included under the term Anishinaabeg speak a closely related and mutually intelligible language. The name Anishinaabeg has been translated variously to mean spontaneous people, first people or good people. I will use the term when describing the broad experience of many bands in the region or when describing mixed tribal groups. See Basil Johnston, Ojibway, Heritage, (Lincoln: University of Nebraska Press, 1990), p.15; William W. Warren, History, of, the,.Ojibway, People, (St. Paul: Minnesota Historical Society Press, 1984), p.37.

${ }^{2}$ Richard White's influential book The,Middle, Ground: Indians, Empires, and Republic, in, the Great, Lakes Region, 1650--1815 (New York: Cambridge University Press, 1991) concludes with the War of 1812 yet subsequen scholars have demonstrated that the process of accommodation and the search for common meaning that White documented in an earlier period continued. See Keith R. Widder, Battle for the, Soul: Metis, Children, Encounter Evangelical, Protestants, at,Mackinaw,Mission, 1823-1837, (East Lansing: Michigan State University Press, 1999), Susan Sleeper-Smith, French,Men, and,Indian,Women:,Rethinking,Cultural,Encounter, in, the, Western, Great, Lakes (Amherst: University of Massachusetts Press, 2001) $i_{\bar{\nu}}$ Theodore J. Karamanski, Blackbird's, Song:Andrew,J. Blackbird and the, Odawa, People (East Lansing: Michigan State University Press, 2012); Anne F. Hyde, Empires, Nations, and, Families: ANew, History, of, the,North,American,West, 1800-1860, (Lincoln: University of Nebraska Press, 2012). More recently in An,Infinity, of Nations Michael Witgen makes the case that strong lindigenous sovereignty in the Great Lakes region lasted well -into the nineteenth century, a thesis better supported by events in Minnesota than further east in the region, such as in Michigan, Illinois, and Ohio. Michael McDonald inasters of Empire: Great Lakes Indians and the Making of A merica (New York: Hill \& Wang, 2015)also takes issue with the concept of the Great Lakes as a "middle ground" and especially White's characterization of the Anishinaabeg as a "shattered" people in the wake of the Iroquois wars as does Robert Michael Morrissey. See Michael McDonald, Masters of Empire: Great Lakes Indians and the Making of America (New York: Hill \& Wang, 2015); Robert Michael Morrissey, in "The Power of the Ecotone: Bison, Slavery, and the Rise and Fall of the Grand Village of the Kaskaskia," Journal of,American,History Vol.102, nNo. 3 (Dec.ember, 2015),_p.667_-692.

Formatted

Formatted: Indent: First line: $0.5^{\prime \prime}$
} 
established cultural norms.-_This process did not take place in the area south of Lakes Erie and Michigan.-_Here the old fur trade ways were swept away by a quickly rising tide of agricultural settlers.-_Yet during the 1820s the Anishinaabeg of the northern Great Lakes faced no such direct pressure and were allowed time in which they could take stock of their relations with the American state and to initiate strategies of resistance and accommodation.

___ _ _ Several Anishinaabeg bands adopted bold strategies designed to both frustrate a United • States_-_government intent on carrying_-out the policy of Indian removal and to reposition their bands in the changing economy and politics of the ante-bellum era.-_The United States government had a two-faced policy toward indigenous peoples._-_On one hand, it was committed to the taking of Indian land in order to accommodate its swelling agricultural population, yet it also claimed to be committed to “civilizing” Indians so they could eventually be incorporated into the general population.-_In 1821 Lewis Cass, the Governor of the Michigan Territory (which then embraced the entirety of the Upper Great Lakes region), visited the people of the region. Accompanying him was Reverend Jedidiah Morse who encouraged the Indians to accept Christian missionaries with the threat “Civilization or ruin.”-_Faced with this pressure, two groups of Anishinaabeg, independent of each other, elected to embrace a path to "civilization,” but in such a way that it was under their control.-_These were the Potawatomi in southwestern Michigan under the leadership of Leopold Pokagon and the Odawa in the Little Traverse Bay area of northwestern Michigan, under Apokisigan and Mackadepenessy. Spurning Protestant missionaries offered by the government, they solicited instead the assistance of the Roman Catholic Church.-_In a series of petitions the Odawa Mackadepenessy sent to the Pope in Rome, the President of the United States, even the King of France, he specifically requested Jesuit missionaries.-_In doing, this they were reviving a relationship that went back to the Jacques 
Marquette, S._J. and the black robes of the seventeenth and eighteenth centuries as well as making common cause with the French and Metis (mixed bloods) who still played a dominant role in the European_-American commerce of the region._-At the same time they selected a branch of Christianity that was decidedly independent, almost at odds, with the settler state that threatened them._-_By this path the Anishinaabeg could increase their access to a new source of sacred power, claim to have embarked on the path to civilization, yet also keep the United States government at bay.- ${ }^{3}$

The embrace of Catholicism by several Anishinaabeg bands was calculated, but it would be wrong to see it as purely political.-_In the wake of the War of 1812, the native people of the Great Lakes were in crisis._-_Military means of defending their homeland had failed and the old fur trade economy was faltering.___A new source of spiritual power was needed as well as a new tactic to deal with the American state.-_The marginal status of the Catholic Church allowed Indian leaders to control the pace of change.-_So weak was the Catholic Church in Michigan in 1823, the date of the first Odawa petitions, that there was only a single priest in the entire territory._-For several years the Odawa actually carried out a process of self-evangelization in which tribal lay ministers exposed to the new faith in the East taught prayers, built a chapel, and even began instruction in literacy. By the 1830s the Catholic Church in the United States was finally strong enough to send resident missionaries. Indigenous autonomy in the process, however, remained strong.--_This was in part because among the Odawa, the missionaries sent by the Church came from Slovenia. They spoke, Latin, French, Slovenian, German, and worked to

\footnotetext{
${ }^{3}$ John C, Shea, Catholic Missions Among the Indian Tribes of the United States (New York: E. Dunigan \& Brother, 1854), p.383; James A. Clifton, The Pokagons, 1683-1983: Catholic Potawatomi Indians of the St. Joseph River Valley (Lanham, MD: University Press of America, 1984), p.66--69; Petition of the Chiefs of the Ottawa Indians, Arbre Croche to the President of the United States, 12 August 1823, Chronological File, Manuscripts Division,

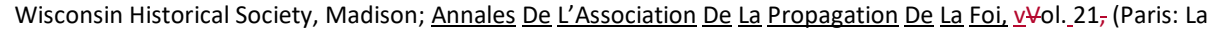
Librairie Ecclesiastique De Rusand, 1826) p-121_-35; -Karamanski, Blackbird's Song, p.-36--38.
}

Formatted: Font: Not Italic, Word underline

Formatted: Font: Not Italic, Word underline 
become fluent in Anishinaabeg languages as well.-_Their lack of English language skills and knowledge of America, however, limited their ability to meddle in the Odawa's relations with the United States.-_The embrace of Catholicism enabled the Pokagon band of Potawatomi to avoid their removal from the Michigan Territory. At the 1833 Treaty of Chicago they were excluded from the order to remove west and initially instructed to relocate among their coreligious Odawa near Little Traverse. Later they received their own reservation in southern Michigan. The Odawa of Little Traverse used the 1836 Treaty of Washington to secure what were initially promised to be large permanent reservations in their homeland.__After they returned to Michigan, the Senate "revised" the agreement and limited their tenure there to a mere five-year period before removal.-_Yet like the Pokagon, the Odawa were able to frustrate removal by using the funds received for the sale of their western Michigan estate to makeby making private land purchases._-_Federal treaties also guaranteed the Anishinaabeg the right to hunt and fish on the ceded territory until it was "required for settlement.”-_This proved important for the Odawa who were actively engaged in commercial fishing for America's growing urban markets.-_Many other Anishinaabeg bands, particularly those in southern Michigan, did not fare so well and suffered removal or simply outright dispossession.-_The Ojibwe of Swan Creek, Black River, and Saginaw Bay in eastern Michigan were systematically stripped of their estate by a series of treaties between 1837 and 1838. Decimated by smallpox a small number accepted removal to Kansas while the remnant took refuge in a series of Methodist mission settlements. ${ }^{4}$

\footnotetext{
${ }^{4}$ Petition of the Chiefs of the Ottawa Indians, Arbre Croche, AugustAug. 12, 1823, Chronological Files, Manuscripts Division, Wisconsin Historical Society, Madison, Wisconsin; P. Chrysostomus Verwyst, Life and Labors of $\underline{\text { St. Rev, }} \underline{\underline{\text { Rev }}}$

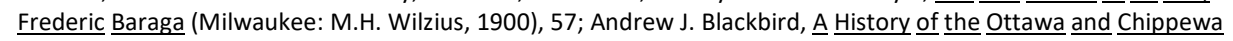

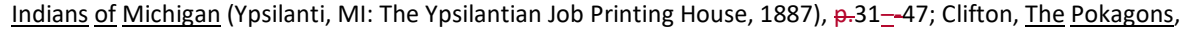
p-66--69; Charmaine M. Benz, editored., Diba Jimooyung: Telling Our Story, A History of the Saginaw Ojibwe Anishinabek (Mt. Pleasant, MI: Saginaw Chippewa Indian Tribe of Michigan and the Ziibiwing Cultural Society, 2005), p.44--51.
} 
The Panic of 1837, which practically brought to a halt the settlement of Michigan by European_-Americans, and the fact that the lands of central and northern Michigan were less attractive to agriculturalists than prairie tracts further west also played a role in allowing some indigenous people in to avoid removal.-_-The fact remained, however, that as the decade of the 1840s ended Michigan, unlike other $\underline{m M i d w e s t e r n ~ s t a t e s ~ s u c h ~ a s ~ O h i o, ~ I n d i a n a, ~ a n d ~ I l l i n o i s, ~}$ continued to have a large indigenous population.-_Some like the Odawa in the northwest had their own land base and others like the Saginaw Ojibwe were largely landless and indigent.-_The question of how the State of Michigan should deal with the populations left by the old fur trade era became an issue at a convention called in 1850 to draft a new Michigan constitution. Representatives from northern Michigan were determined that mixed-bloods who descended from Anishinaabeg and European relationships be recognized a citizens with full civil rights. They were a sizable portion of the community and a handful were among the leading business men and women in the region.-_Therefore, when the 1850 constitution was approved, it included a clause stating that every "male inhabitant of Indian descent, a native of the United States and not a member of a tribe” be recognized as a citizen.-_This carefully worded legal change became very broadly interpreted due to the activism of the Odawa Andrew J. Blackbird.-_He was the educated son of Mackadepenessy whose petitions had first brought Catholic mission schools to Little Traverse Bay._-_Blackbird lobbied the State Chief Justice, the governor, and the legislature to include not just mixed-bloods but all Indians wishing to be citizens.--It seems state officials saw this as a long-term solution to the state’s "Indian Problem.”-_Blackbird even prevailed upon the legislature to send a formal resolution to Congress requesting that the federal government 
make "arrangements" for the "permanent location” of the Anishinaabeg "in the northern part of this state.”- 5

The solution to the Indian problem in Michigan foreshadowed the Dawes Act approach the government would adopt three decades later.-_In 1855 the federal government recognized Michigan Indian's new civil status and the fact that removal was neither feasible nor desirable. Commissioner of Indian Affairs George Manypenny negotiated a new series of treaties with the Anishinaabeg.- The 1855 Treaty with the Odawa and Ojibwe of northern Michigan created a series of reservations of public land from which tribal members could select family allotments of eighty acres. While Indians could occupy the land immediately upon selection, actual title to the land would be held in trust by the federal government for a period of ten years.-_A similar treaty was made with the Saginaw area Ojibwe.-_The treaties also set up a series of schools for Indian youths to be funded for ten years.-_Once tribal land allotment was concluded, the areas set aside as reservations would be open to all interested buyers. It is significant and reflective of the optimism of Manypenny and indeed the State of Michigan that the trust period for these allotments was only set at ten years not the twenty-five later incorporated in the Dawes Act.- ${ }^{6}$

With the 1855 treaties the federal government thought it had laid out a program by which it would be free of Indian responsibilities in Michigan within ten years. While Michigan remained the largest Indian agency in the country and it operated the largest government school system in the nation, the plan was for all trust responsibilities and treaty liabilities to end in ten years. At

\footnotetext{
${ }^{5}$ Kenneth E. Lewis, West, to Far.Michigan: Settling the Lower, Peninsula, 1815--1860 (East Lansing: Michigan State University Press, 2002), , p.112_-13; Susan E. Grey, The Yankee,West: Community, Life, of the Michigan, Frontier (Chapel Hill: University of North Carolina Press,1996), p.47--50, 72; Michigan, Statutes,Annotated: Containing, the Text,of,All,General,Laws, of,a, Permanent, Character, ,in, Force, in,Michigan, vvolume. 1 (Chicago: Callaghan, 1882),

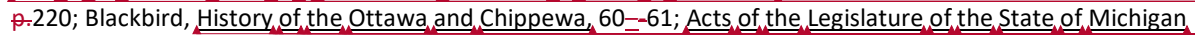
(Lansing: R.W. Ingalls, 1851), p.258--59; Deborah Rosen, American, Indians, and State, Law: Sovereignty Race, and Citizenship, 1790--1880 (Lincoln: University of Nebraska Press, 2007), p-128--36.

${ }^{6}$ Charles J. Kappler, Indian, Treaties, 1778--1883, (New York: Interland Publishing, 1972),_p.727--29, 733--35; 
that point the tribal status of the Odawa and Ojibwe would cease and they would simply be state citizens.-_The Odawa and Ojibwe thereby successfully evaded the federal removal program. This was in part because of their strategic response to American pressure and in part because agriculturally focused American settler colonialism by-passed their homeland in favor of transMississippi prairie lands.-_The greatest challenge for the Anishinaabeg, however, lay in front of them in the form of the European_-American logging frontier.

\section{The Logging Frontier}

_ Settler $\underline{\text { c }}$ Colonialism is a transnational process by which an incoming population displaces the indigenous people and establishes their own sovereign regimes. In the words of the Australian anthropologist Patrick Wolfe “settler colonialism destroys to replace.”_-_Like all forms of settler colonialism, the logging industry brought a transformative socioeconomic system, one that had been perfected in the forests of New England to the Great Lakes region. The logging frontier was a facet of European_-American colonialism that was vastly different than the agriculturally based settlement system that succeeded in displacing indigenous people in the

Ohio Valley and along the lower Great Lakes.-_Lumbermen were like the fur traders that first encountered the Anishinaabeg in only one significant way, they were focused on acquiring a single resource from the Great Lakes environment, and they were content to destroy that resource in the process of acquiring it. ${ }^{7}$

\footnotetext{
7 Patrick Wolfe, "Settler Colonialism and the Elimination of the Native ${ }_{L}$ " Journal of Genocide Research 8, no._4 (Dec. 2006), 387-409. See also Lorenzo Veracini, Settler Colonialism: A Theoretical Overview (New York: Palgrave Macmillan, 2010), 17; Although the author does not deal with the lumber industry, for a treatment of settler colonialism in the Great Lakes region, see Bethel Saler, The Settler's Empire: Colonialism and State Formation in America's Old Northwest (Philadelphia: University of Pennsylvania Press, 2015).
} 
Unlike the fur traders European_-Americans interested in accessing logs for lumber did not require Indian labor to secureaceess this resource.-_The Anishinaabeg had hunted furs for their own use for centuries before the arrival of the Europeans, and they brought to the trade the skills necessary to most efficiently acquire and process the desired product.-_Although the indigenous people of the Great Lakes forest had prodigious wood working skills, logging on a commercial scale was not something that indigenous people practiced._-_t brought a transformation of the environment they had not ever even imagined._-_In Michigan as well as most of the Great Lakes region, Indians were drawn into participating in the lumber industry as lumberjacks and river drivers._-_Indians who in the 1870s and 1880s took jobs as loggers did so out of a need for cash income following the loss of land tenure.-_Some native communities even managed a number of small logging operations on their own, however, unlike the fur trade. it was Indian land not indigenous labor which was crucial to the economic enterprise. ${ }^{8}$

While both the fur trade and the lumber industry relied upon what European_-Americans regarded as "wilderness" landscapes for their extractive pursuits, the lumber industry faced daunting logistical challenges as it sought to establish itself in the region.-_The fur trade had been an ideal economy for a remote region since it revolved around the harvesting and transport of a light-weight, high-value product.-_In contrast, the lumber industry focused on a heavy, unwieldy, product that was of commercial value only in large volume.-_Removing timber from the forest, transporting to where it could be milled and getting it to a market was the economic challenge of the lumber industry as it moved into the Great Lakes region._-_Since this

\footnotetext{
${ }^{8}$ For Michigan Indian participation in logging see: Annual, Report, of, the, Commissioner, of.Indian, Affairs, 1875, p.294; George I. Betts to Commissioner of Indian Affairs, 26 MarchMar. 26, 1874, National Archives, RG 75, M-234, Roll 411, p.46: John W. Fitzmaurice, The, Shanty, Boy, or, Life, in, a, Lumber, Camp, (Cheboygan, MI: Democratic Steam Press, 1889), p.8; James McClurken, "Wage Labor in Two Michigan Indian Communities," Native.Americans, and Wage,Labor; Ethnohistorical, Perspectives, dited byed. Alice Littlefield and Martha Knack (Norman: University of Oklahoma Press, 1996), p.75--79. 
necessitated considerable capital investment, there were few industrial scale attempts at exploiting forest resources until treaties of cession had reduced indigenous title to the land of the Upper Great Lakes region. The lumber industry’s transformative socioeconomic system differed profoundly from agricultural settlement.-_It brought only a small permanent population but required a broad appropriation of forest lands._-_During the pine logging phase of the industry which began in the 1840s, accelerated in the 1860s, and climaxed in Lower Michigan in the 1880s, temporary lumber camps were established in the interior to plunder the surrounding area and then after a season or two relocate to a new site._-_Cut timber was floated downstream usually to lakeshore urban settlements where it could be milled and shipped by schooner to market. Lumbermen's occupation of the land was fleeting but often devastating to the environment.-_While agriculturalists usually planted homesteads with an eye to permanent occupation, lumbermen sought the main chance for the short_-run._-_The lumber industry variation on settler colonialism did not require the complete displacement of the indigenous population so long as forest resources could be appropriated.-_Hence native people could persist in their homelands in spite of logging as long as their control over the forest was broken.-_Even after pine logging was completed in a region, the lands remained integrated into the Anglo_American settler state to be exploited for their hardwood trees and later for so-called "weed trees” for pulpwood, or to become hardscrabble cut-over farms. ${ }^{9}$

\footnotetext{
${ }^{9}$ There were three basic phases through which the Great Lakes logging frontier progressed. The chronology is somewhat different for each state in the region as the industry basically moved west from Michigan, Wisconsin, to Minnesota. The first phase was pine and cedar logging because these softwoods floated and could be easily moved by water. They were also in great demand for balloon frame construction. Hardwood logging usually required railroads and came later followed by pulpwood logging eventually relying upon internal combustion engine equipment. For the phases of logging industry exploitation see- Theodore J. Karamanski, Deep,Woods, Frontier: A History of Logging in Northern Michigan (Detroit: Wayne State University Press, 1989). For more on the logistics of frontier logging see; Michael Williams, Americans and their, Forests: AHistorical Geography (New York: Cambridge University Press, 1992), p.193_-230; William Gerald Rector, Log Transportation, in , Lake, States, Lumber, Industry, 1840-1918 (Glendale, CA: Arthur H. Clark Company, 1953).
} 
The first industrial use of the forest resources of the Upper Great Lakes region was by the shipping industry.-_In the 1840s more than 300 -three hundred steamboats plied the Great Lakes carrying cargoes and settlers from the Erie Canal at Buffalo to Chicago and other points west. Mostly powered by wood, these vessels were required to make numerous stops to replenish their supply of fuel. Cordwood stations were set up all along the lakeshore by entrepreneurs who freely cut down trees on government or even unceded Indian land. Prior to the cession of their lands, Indians complained to federal authorities about this intrusion upon their resource base. In 1834 the Odawa headman Pabanmitabi insisted "if any wood is cut upon our land ...we should be paid for it.” The timber on islands and peninsulas was the easiest to exploit since it was adjacent to maritime transportation and many of those sites were denuded to feed steamship fireboxes. The habit of stealing timber only increased following the cession of most Indian land in Michigan in 1836. ${ }^{10}$

From the middle to well after the turn of the nineteenth century, the Great Lakes region was caught up in a green gold rush in which timber created more millionaires than the California Gold Rush.-_The value to come out of Michigan’s deep woods alone far outstripped the value to come from California gold mines between 1849 and 1900.--_This logging frontier was shaped by the economics of harvesting and processing large amounts of standing timber into lumber. Lumbermen had four big expenses: the acquisition of standing timber, the cutting of the trees into logs, the transportation of the logs to the site of a mill, and milling of the logs into dimension lumber (to this could also sometimes be added the transport of the lumber to a market).-_The opportunity for profit could be enhanced by reducing or eliminating the cost of any of those necessary steps.--The logging frontier's particular brand of settler colonialism

${ }^{10}$ Speech of Pabanmitabi, 18 AugustAug. 18, 1834, National Archives, Letters Received by the Superintendents, Michigan Superintendency, 1818_-1835, RG 75, M-1, Roll 69, p.79. 
flowed out of lumberman's inevitable conflict and occasional cooperation with Anishinaabeg.

The logging frontier provided occasional employment of native people in cutting or floating logs, but also impinged upon usufruct rights, resulted in timber theft, and the fraudulent taking of Indian land. ${ }^{11}$

Pioneer logging ventures brought little benefit and some disruption to indigenous people. In the 1850 s and 1860 s Indian men were not considered competent to join the lumberjacks in felling and transporting trees. This seems to have stemmed from longstanding white fear and mistrust of Indians by European_-Americans as well as the fact that few Anishinaabeg could speak English and, therefore, could not work effectively with logging crews._-_t was not until the 1870s and later that Indians with the necessary language skills began to join the shanty boys as sawyers, swampers, and river drivers.-_What early logging brought to Indian country was a disruption of traditional subsistence practices._-Fish weirs that had been used and maintained for generations were often torn apart to clear rivers and streams for the spring log drive.--Those changes further compromised aboriginal subsistence by ruining spawning areas along rivers through siltation and changes in water temperature._-_Berry patches and maple sugar groves could also be disrupted, especially in later years when hardwood trees were targeted by loggers.-_In Wisconsin and Minnesota where wild rice that grew along the rivers was a critical part of the Anishinaabeg diet, loggers drowned the crop by raising water levels for log drives.-_The Ojibwe sometimes respond to this by opening dams or even tearing them down, which brought

\footnotetext{
${ }^{11}$ For the comparative value produced by the logging frontier see, "Green Gold," Michigan Educational Portal for Interactive Content, http://w michigan-history.org/greengold/GGEducatorNotes.html, accessed August, 2015. For more on the economics of the logging industry see, Joseph Zaremba, Economics, of the, American,Lumber Industry (New York: R. Speller, 1963). Fand for a more focused look at Michigan logging see Barbara E. Benson, "Logs and Lumber: The Development of the Lumber Industry in Michigan's Lower Peninsula, 1837--1870" (, Ph.D. dissertationdiss., Indiana University, 1976); ; and Karamanski, Deep.Woods, Frontier. For an excellent study of how the Anishinaabeg of the Upper Peninsula of Michgan adapted to the logging industry in the early twentieth century see, Bradley J. Gillis, Navigating the Landscape of Assimilation: The Anishnabeg, the Lumber Industry, and the Failure of Federal Indian Policy in Michigan, Michigan Historical Review Vol. 34, no.2 (Fall 2008): 57-74.
}

\begin{tabular}{|l|}
\hline Formatted: Font: Not Italic, Word underline \\
\hline Formatted: Font: Not Italic, Word underline \\
\hline Formatted: Font: Not Italic, Word underline \\
\hline Formatted: Font: Not Italic, Word underline \\
\hline Formatted: Font: Not Italic, Word underline \\
\hline Formatted: Font: Not Italic, Word underline \\
\hline Formatted: Font: Not Italic, Word underline \\
\hline Formatted: Font: Not Italic, Word underline \\
\hline Formatted: Font: Not Italic, Word underline \\
\hline Formatted: Font: Not Italic, Word underline \\
\hline Formatted: Font: Not Italic, Word underline \\
\hline Formatted: Font: Not Italic, Word underline \\
\hline Formatted: Underline \\
\hline Formatted: Font: Not Italic, Underline \\
\hline Formatted: Underline \\
\hline Formatted: Font: Not Italic, Underline \\
\hline Formatted: Font: Not Italic, Word underline \\
\hline Formatted: Font: Not Italic, Word underline \\
\hline
\end{tabular}


confrontations with the angry lumber men.-_In 1854 the most serious of these disputes occurred over a logging dam at the source of Minnesota’s Rum River that destroyed wild rice grounds on Mille Lacs._-_Following disputes that left two lumberjacks and one Ojibwe dead, the U.S. Army and the Minnesota governor intervened and eventually the Mille Lacs band received compensation for their crop loss. ${ }^{12}$

As the logging industry developed in the Great Lakes region, it was marked by a diversity of participants from small, poorly capitalized entrants into the trade to large-scale operators with vertically integrated corporations that captured all stages of production from the forest to mill and market.__Another crucial facet of logging was that it necessitated substantial up-front capital out-lays before any profit could be accrued.-_For example, a small operator attempting to enter the business, had to purchase timberlands, build a lumber camp, hire, equip, and feed a logging crew for four to five months, and move hundreds of large logs to a mill all before any profit could be realized.-_That heavy burden of capital out lay encouraged logging operations to frequently seek illegal means to reduce cost._-_The easiest way to do that, especially in the 1850s and 1860s when the region was sparsely inhabited was to cut logs on unpurchased, usually government, and sometimes Indian land. ${ }^{13}$

Timber stealing on public land began in the 1830s and grew to such sizeable portions in the 1850s that the Department of the Interior had to appoint agents to northern Michigan, Wisconsin, and Minnesota. They were charged with investigating cases of illegal logging,

\footnotetext{
12 James McClurken, "Wage Labor in Two Michigan Indian Communities," Native Americans and Wage Labor: Ethnohistorical Perspectives, ed. Alice Littlefield and Martha Knack (Norman: University of Oklahoma Press, 1996), 75-79; Charles Cleland, "Preliminary Report of the Ethnohistorical Basis of the Hunting, Fishing, and Gathering Rights of the Mille Lacs Chippewa," Fish in the Lakes, Wild Rice, and Game in Abundance: Testimony on Behalf of Mille Lacs Ojibwe Hunting and Fishing Rights, edited byed. James McClurken (East Lansing: Michigan State University Press, 2000), p.76; Eileen M. McMahon and Theodore J. Karamanski, North Woods River: The St. STroix Valley in Upper,Midwest History (Madison: University of Wisconsin Press, 2009),_p-76--77, 96-_97.

${ }^{13}$ Bensen, "Logs and Lumber," p-3--5.
}

\begin{tabular}{|l|}
\hline Formatted: Font: Not Italic, Word underline \\
\hline Formatted: Font: Not Italic, Word underline \\
\hline Formatted: Font: Not Italic, Word underline \\
\hline Formatted: Font: Not Italic, Word underline \\
\hline Formatted: Font: Not Italic, Word underline \\
\hline Formatted: Font: Not Italic, Word underline \\
\hline Formatted: Font: Not Italic, Word underline \\
\hline Formatted: Font: Not Italic, Word underline \\
\hline Formatted: Font: Not Italic, Word underline \\
\hline Formatted: Font: Not Italic, Word underline \\
\hline Formatted: Font: Not Italic, Word underline \\
\hline Formatted: Font: Not Italic, Word underline \\
\hline Formatted: Font: Not Italic, Word underline \\
\hline Formatted: Font: Not Italic, Word underline \\
\hline Formatted: Font: Not Italic, Word underline \\
\hline Formatted: Font: Not Italic, Word underline \\
\hline Formatted: Font: Not Italic, Word underline \\
\hline Formatted: Font: Not Italic, Word underline \\
\hline Formatt: Font: Not Italic, Word underline \\
\hline Formt: Not Italic, Word underline \\
\hline Formatted: Font: Not Italic, Word underline \\
\hline Font: Not Italic, Word underline \\
\hline Fot Italic, Underline \\
\hline Formatted Italic, Word underline \\
\hline Formated
\end{tabular}


confiscating the logs or lumber, and working with the United States District Attorney to prosecute the guilty parties._-_In 1854 agent Isaac Willard took a small boat up the Lake Michigan shore from Grand Haven to past Manistee, Michigan, and he found innumerable trespasses upon the public lands.-_Thirty-seven indictments followed including for violations of an Ojibwe reservation at Manistee.-_The Indians had objected to the initial intrusion of the lumbermen, but the hungry members of the local band had been bought off with gifts of pork and flour.-_- The Ojibwe were less accommodating on Wisconsin's St. Croix River when a group of warriors stopped a log drive with the notice "We have no money for logs; we have no money for land. Logs cannot go.”-_Those words backed by an implicit threat of violence proved more effective than federal agent arrest warrants._-_In what proved a foreshadowing of what was to come, ante-bellum agents in Michigan proved better at identifying timber thefts than stopping the practice. The federal agents were not able to secure the cooperation of local officials, ship owners, or even the compliance of the local community who saw their economic self-interest resting with the timber thieves.-_Timber thefts only increased in succeeding decades, and by 1879 it was such an issue that President Rutherford B. Hayes mentioned the problem in his State of the Union message and requested specific legislation to speed prosecution. While the federal government struggled to come to terms with timber thefts it did act as an agent for the logging industry in pushing for the Anishinaabeg to cede their lands in exchange for reservations. The St. Croix Ojibwe, who were among the first bands confronted with lumber industry expansion, were well aware the white men wanted their pine timber. In treaty negotiations with the United States they sagely proposed to cede their lands for the term of sixty years, "It is hard to give up the lands. They will remain and cannot be destroyed but you may cut down the trees and others will grow up.” The government, however, insisted on taking full title to their homeland. Sixty years 
later the St. Croix valley was a devastated cutover and most of the lumbermen had moved further west.- ${ }^{14}$

\section{Logging and Anishinaabeg Land Loss}

Even where Indian land tenure seemed to be under close federal supervision, lumbermen developed sophisticated methods of cheaply gaining control of tribal forest resources.-_The lumber industry’s assault on the Saginaw Ojibwe’s reservation in central Michigan illustrates these tactics.-_In 1855 parts of six townships were reserved for the Ojibwe to make allotment selections and land purchases._-_Allotments were supposed to take place in 1855 and 1856 and then the Indians were to have a decade of federal stewardship to protect their title to the land. Instead, multiple agents so bungled the allotment process that a decade later there was no certainty who owned what land._-_Several times allotment took place, but lists were either poorly recorded or lost before they could make their way to Washington.-_It was not until 1870 and 1871 that the Michigan Anishinaabeg received federal patents on their land.-_By this time the Michigan lumber industry was the most powerful political and economic force in the state.-_In Washington the lumber men used their influence with the Office of Indian Affairs to have the majority of Ojibwe allotees ruled as “competent” and, therefore, able to own and sell their land

\footnotetext{
${ }^{14}$ Isaac W. Willard to Robert McClelland, Secretary of the Interior, 18 FebruaryFeb. 18, 1854, House Document nNo. 15,- House Documents, Otherwise, Published as Executive Documents: Thirteenth Congress, second session (Washington, DC: A.O.P. Nicholson, 1854), 11-17; Jennifer Herman, "Manistee," Michigan Encyclopedia (St. Clair Shores, MI: Somerset Publishers, 1999), p.383; “The Nation: Annual Message of the President to Congress Not Assembled," Chicago Tribune, Nov. 30, 1879; McMahon and Karamanski, North Woods River, p.77; W.H.C. Folsom, Fifty Years in the Northwest, ed. E._E. Edwards (1888 reprint; Taylor's Falls, MN: Taylors Falls Historical Society, 1999), 99; "Treaty with the Chippewa, 1837," Indian Treaties, 1778--1883, Edited byed. Charles J. Kappler (New York: Interland, 1972), 491-92; Charles E. Cleland, "Preliminary Report of the Ethnohistorical Basis of Hunting, Fishing, and Gathering Rights of the Mille Lacs Chippewa," Fish in the Lakes, Wild $\underline{\text { Rice, }} \underline{\text { and }} \underline{\underline{\text { Game }}} \underline{\underline{\text { in }}} \underline{\text { Abundance}}$, ed. James M. McClurken (East Lansing: Michigan State University Press, 2000), 31.
}

\begin{tabular}{|l|}
\hline Formatted: Font: Not Italic, Word underline \\
\hline Formatted: Font: Not Italic, Word underline \\
\hline Formatted: Font: Not Italic, Word underline \\
\hline Formatted: Font: Not Italic, Word underline \\
\hline Formatted: Font: Not Italic, Word underline \\
\hline Formatted: Font: Not Italic, Word underline \\
\hline
\end{tabular}

\begin{tabular}{|l|}
\hline Formatted: Font: Not Italic, Word underline \\
\hline Formatted: Font: Not Italic, Word underline \\
\hline Formatted: Font: Not Italic, Word underline \\
\hline Formatted: Font: Not Italic, Word underline \\
\hline Formatted: Font: Not Italic, Word underline \\
\hline Formatted: Font: Not Italic, Word underline \\
\hline Formatted: Font: Not Italic, Word underline \\
\hline
\end{tabular}


without federal oversight.-_The Office of Indian Affairs ruled the trust time had lapsed and local agents were given the authority to determine who was “competent.”-_Most new land owners were declared “competent” and immediately set upon by lumbermen offering to buy their land or the right to cut their timber.-_Some Ojibwe committed to farming accepted the offer to have their timber cut in order to clear the land and to raise capital to buy livestock, seed, and build a home. Others went to their allotments only to find that the timber had already been cut by loggers who had purposely cut what was known as a "round forty" - a practice in which loggers operating legally on say a forty acre track would purposely stray on to the adjoining land and denude it of timber._-All too often such operators moved on before they could be brought to justice.-_Yet worse abuse was to come. ${ }^{15}$

The Methodist Church had done much to help the Saginaw Ojibwe adjust and even rebound from the land loss of the treaty era and the collapse of the old fur trade economy._-Yet that institution was also deeply involved in the politics of nineteenth century Michigan.-_For two decades the Methodist Church all but had a hammer lockhammerlock on the Michigan Indian Agency._-_Long before the celebrated “Peace Policy of General Grant” most agents were Methodist ministers or elders in the Church whose selection was approved by the Church.-_-Some of the agents were mell-meaningwell meaning if not especially competent, some were corrupt and in league with some of the leading lumbermen in the region.-_In 1868_-1869 Reverend George Bradley received payments from lumbermen for convincing his Indian congregation to

\footnotetext{
${ }^{15}$ The federal action declaring unprepared Anishinaabeg "competent" to sell their allotments was another example of where Michigan Indian policy foreshadowed the abuses of the Dawes Act era. J. Usher to J. Edmunds, $z$ DecemberDec. 2, 1864, Petition of Frederick Hall, $40^{\text {th }}$-Fortieth Congress, $3^{\text {rd }}$-Secessionthird session, House of Representatives, Misc. Document nnNo._40, January, 1869; George Bradly to Eli Parker, Commissioner of Indian Affairs, 4 NovemberNov. 4, 1869, National Archives, M-234, Roll 408: p.894--897; Report of the Commissioner of Indian Affairs, 1870 (Washington, DCD.C:: Government Printing Office, 1870), p.780; Benz, editored., Diba

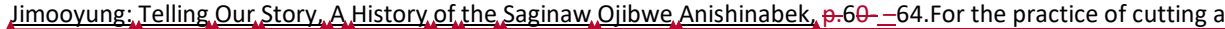
"round forty" see Karamanski, Deep,Woods, Frontier, p-99-100. 
sell the timber rights on their allotments at prices well_below market value and did so even before the allotment process was completed.-_He was later elevated to the office of Indian Agent.-_Even worse was the career of Reverend George Betts who served as Indian Agent from 1871 to 1876 .-_-Betts entered into a lucrative partnership with a cabal of local lumbermen. As agent Betts issued allotments to Indians within the Isabella reservation, declared them "competent," then he would immediately pass on the information to lumbermen who could target the new land owners.-_Many were unaware of how valuable good pine tracts were.-_-One Ojibwe who had been declared “competent” sold his timber for fifteen dollars $\underline{\$ 15}$ to a lumberman who later laughed that the trees were worth \$4,000._Even more effective at turning over reservation land to the lumbermen was Betts’s practice of issuing patents to non-existent or deceased individuals._-_Perhaps as many as four_-hundred such patents were issued leading to the immediate plundering of the valuable timber on the land.-_Complaints about Betts's corruption began to pile up in Washington within a year of his taking office, yet no official investigation took place until January 1876._-_He was eventually terminated and several thousand acres of land were returned to the reservation, however, Betts never faced criminal charges and he escaped with a small fortune. ${ }^{16}$

An important part of the lumbermen's tactics to defraud the Ojibwe was complicity by their fellow tribesmen.-_John Irons, a Methodist preacher and tribal member, was an active agent of the lumber companies.-_Another Ojibwe John M. Collins used his position as the official interpreter on the Isabella reservation to promote Betts’s bogus allotments to the local chiefs. His deal with local logger Irving Arnold netted Collins fifteen dollars $\$ 15$ for every allotment he

\footnotetext{
${ }^{16}$ Edward C. Kemble, Special Inspector, Office of Indian Affairs to J. Q. Smith, Commissioner of Indian Affairs, 22 FebruaryFeb. 22, 1876, National Archives, H-211, document 2946; Warranty Deed, Caw-bay-quomo-quay to Peter Andre, 15-Jan. 15, tary 1878, Andre Papers, Bentley Historical Library, University of Michigan, Ann Arbor; Benz, editored., Diba Jimooyung: Telling Our Story, A History of the Saginaw Ojibwe.Anishinabek, p.65--68.
}

\begin{tabular}{|l|}
\hline Formatted: Font: Not Italic, Word underline \\
\hline Formatted: Font: Not Italic, Word underline \\
\hline Formatted: Font: Not Italic, Word underline \\
\hline Formatted: Font: Not Italic, Word underline \\
\hline Formatted: Font: Not Italic, Word underline \\
\hline Formatted: Font: Not Italic, Word underline \\
\hline Formatted: Font: Not Italic, Word underline \\
\hline Formatted: Font: Not Italic, Word underline \\
\hline Formatted: Font: Not Italic, Word underline \\
\hline Formatted: Font: Not Italic, Word underline \\
\hline Formatted: Font: Not Italic, Word underline \\
\hline Formatted: Font: Not Italic, Word underline \\
\hline Formatted: Font: Not Italic, Word underline \\
\hline Formatted: Font: Not Italic, Word underline \\
\hline Formatted: Font: Not Italic, Word underline \\
\hline Formatted: Font: Not Italic, Word underline \\
\hline Formatted: Font: Not Italic, Word underline \\
\hline Formatted: Font: Not Italic, Word underline \\
\hline Formatted: Font: Not Italic, Word underline \\
\hline Formatted: Font: Not Italic, Word underline \\
\hline Form: Fot Italic, Word underline \\
\hline Font: Not Italic, Word underline \\
\hline Fot Italic, Word underline \\
\hline Formated
\end{tabular}


helped Arnold purchase.-_A number of the Isabella reservation chiefs were aware of Betts's wrong doing yet still supported him in petitions to Washington that helped to delay the agent's removal from office.-_Both Betts and the ring of timber agents who profited off reservation land were skillful at using intra-tribal rivalries and factions to gain the cooperation of Ojibwe leaders. Leaders who one year might complain to Washington about the loss of tribal land could be turned the next year when frustration over government inactivity prompted them to join the rush for profit. In 1878 Chief James Nauckchegame altered the Office of Indian Affairs to a large timber trespass on Indian land.__He provided an exact legal description of the tract and named the individual guilty of the timber theft._-_After nothing was done, it is little wonder that Naukchegame entered into a cooperative arrangement with one of the worst timber thieves. Ojibwe lived in a gold rush atmosphere heated by a post-Civil War culture of corruption that permeated the towns around the reservation with most prominent white men guilty of breaking or manipulating the law with impunity._-_Nonetheless, it was the Ojibwe who profited least and suffered most from the lumber men’s swindles._-_By 1876, through a process that was a largely fraudulent, only a few thousand acres of the more than 92,000 acres that had been set aside as the Isabella Ojibwe Reservation remained in Indian hands. ${ }^{17}$

The tactics employed by lumber frontier settlers toward the Saginaw Ojibwe were also applied to the Odawa in western Michigan.-_The Grand River Odawa had been given a large reservation in Oceana County from which to make individual allotments.-_Less than one year after four_-hundred patents had been issued to these people one timber land speculator had already bought up more than six_thousand acres of land._-_The Odawa were actually in a worse

\footnotetext{
${ }^{17}$ Kemble to Smith, 22 FebruaryFeb. 22, 1876; Petition of the Saginaw Chiefs to Columbus Delano, Secretary of the Interior, 11June 11, 1872, National Archives, H-211, document 5439; Andrew Saw-wa-bon, Johnson Naw-be-tunf, James Nock-che-go-me, and Lyman Bennett to Commissioner of Indian Affairs, n.d. received in Washington, D.C. 22 JuneJune 22, 1878, National Archives, RG 75, M-234, Roll 413, p-730_-732.
} 
situation than the Ojibwe.--_The later had been able to negotiate a Treaty in 1864 that allowed children upon reaching maturity to continue to take allotments as long as there was land available with the Isabella reserve.-_The Odawa, however, were limited to allotments granted to the generation that signed the 1855 treaty with the United States even though the reserves created had much more available land._-_In the 1860s and 1870s the Odawa pressed the government to allow the next generation to also claim allotments.-_Finally, in 1872 Congress addressed the issue.-_Odawa who came of age after the 1855 treaty would be given a six month window of opportunity to claim 160 acres each within either the Oceana County reserve or ones at Grand Traverse Bay or Little Traverse Bay._-_However, these lands were not allotments._-_Instead the land was to be taken under the terms of the Homestead Act which required that claimants dwell on and improve their property for five years before they could be awarded a fee-simple patent. Failure to improve the property or to dwell there could result in a loss of the claim.-_The 1872 law was sponsored by Senator Thomas Ferry who was in league with the lumbermen of the Grand River Valley.-_Their interests were well served by the provision in the law that opened the Odawa reserves to European_-American purchase and settlement once the six-month homestead window closed.-_That same year a railroad connected Little Traverse Bay with the national rail network making the timber resources all the more valuable.__Lumbermen were by no means content with merely being able to purchase the bulk of the timberlands within the Odawa reserves.-_Rather they set about designing tactics to seize the newly claimed Odawa homesteads. $^{18}$

\footnotetext{
${ }^{18}$ Benz, editored., Diba Jimooyung: Telling, Our, Story, A History, of the, Saginaw Ojibwe,Anishinabek, p-64; Senate Bill 1035, A Bill for the Restoration to Market of Certain Lands in Michigan, $42^{\text {nd }}-$ Forty-second Congress, $z^{\text {nd }}$ Sessionsecond session, June 10,10 June 1872, ACentury of Law, Making, for a, New Nation: U.S. Congressional Documents, and Debates, 1774--1875, http://memory.loc.gov/cgibin/ampage?collld=Ilsb\&fileName=42/llsb042.db\&recNum=3251, accessed May, 2010; "Michigan Indians," Chicago, Tribune, July 16, July 1873.
} 
The results were particularly devastating for the Little Traverse Odawa.-_Since the 1820s they had followed a path of resistance through accommodation toward the United States.

Through alliances with the Catholic Church and mixed-blood business-men in the Mackinac Straits area, they had gradually become Christianized. They could read and write text based on a syllabary in their own Anishinaabeg language, and many had become successful participants in the regional economy through commercial fishing and maple sugar harvesting.-_This was an accommodation to the new European_-American economy in the region but one that allowed for continued traditional activities such as pursuit of the seasonal cycle of movement across the land. Band member Andrew J. Blackbird had played a significant role in lobbying the State of Michigan to recognize Indians as citizens while still protecting their treaty rights.-_Beginning in 1856 the Little Traverse Odawa began the work of running the recently created Emmet County, Michigan.-_Educated Indians were elected to positions as deputy sheriff, township supervisor, and in Blackbird's case register of deeds and probate judge and in later years as county treasurer and sheriff.__Almost overnight the Little Traverse band went from being wards of the federal government to masters of their own Michigan local government.-_Indian Agent Henry Gilbert wrote to the Commissioner of Indian Affairs that the Odawa "have an organized county and with some help manage to get along with their business.”-_During the Civil War Odawa young men had served with distinction in the First Michigan Sharpshooters._-_But in the wake of that conflict northern Michigan was transformed by a rising tide of white settlers In 1870 the Odawa made up ninety-five percent of the population of the county and their allotments were still protected in federal trust._-By 1880 there were 5,500 more whites than Indians and most allotments were removed from trust protection.-- The majority of the newcomers were tied to the growing lumber industry as Michigan surged to the forefront in national lumber production._-_As the number of 
European_-Americans grew, the number of Odawa elected to public office shrunk, their role in public life gradually disappeared, and their lands, both allotments and homesteads were in danger. ${ }^{19}$

In the late 1870 s the newcomers began a systematic assault on Odawa lands.-_Andrew Blackbird was drawn into a desperate defense of their individual holdings.-_During the 1860s Blackbird had served as the local representative of the Office of Indian Affairs._-He had been educated at Twinsburg Academy in Ohio and at Michigan State Teachers College.-_Although in the 1870s he did not hold an official position either in the government or tribe, many Odawa turned to him when trouble arose with the European_-Americans._-_Particularly vulnerable were Odawa who had taken homesteads within the Little Traverse reserve.-_A particularly poignant case was that of Lucy Penaseway, an Odawa widow with four young children.-_She had built a comfortable cabin on her claim, planted a garden and the beginnings of an orchard.-_In late summer she and her children left their claim for several weeks to pick berries as was the Odawa tradition._-_When she returned, she found a white family living in her house using her furniture. The white family were stand-ins for what the press called "land sharks" or "timber sharks." They looked for vulnerable Indian claims then approached the Traverse City Land Office clerks to file their own claim on the land on the grounds that the Indians had abandoned it.-_This would necessitate a public hearing.-_The land office would print a notice of the hearing in the Grand Traverse_Herald.-Federal regulations also stipulated that notice of a hearing was to be “personally served” when “practicable.”-_A well placed bribe could ensure that such a personal

\footnotetext{
${ }^{19}$ Emmet County Supervisor's Journal, 1859_-1863 and Statement of Votes, 1855_-1869, Office of Emmet County Clerk, Petoskey, Michigan; Henry Gilbert to Commissioner Manyoneypenny, Dec. 26, 26 December-1856, National Archives, RG 75, Letters Received by the Michigan Superintendency, M-234, Roll 405, p-226. For more on Odawa and Ojibwe service in the Civil War see Raymond J. Herek, These,Men, Have, Seen, Hard Service: The, First,Michigan Sharpshooters in the Civil War (Detroit: Wayne State University Press, 1998).
}

\begin{tabular}{|c|}
\hline Formatted: Font: Not Italic, Word underline \\
\hline Formatted: Font: Not Italic, Word underline \\
\hline Formatted: Font: Not Italic, Word underline \\
\hline Formatted: Font: Not Italic, Word underline \\
\hline Formatted: Font: Not Italic, Word underline \\
\hline Formatted: Font: Not Italic, Word underline \\
\hline Formatted: Font: Not Italic, Word underline \\
\hline Formatted: Font: Not Italic, Word underline \\
\hline Formatted: Font: Not Italic, Word underline \\
\hline Formatted: Font: Not Italic, Word underline \\
\hline Formatted: Font: Not Italic, Word underline \\
\hline Formatted: Font: Not Italic, Word underline \\
\hline Formatted: Font: Not Italic, Word underline \\
\hline Formatted: Font: Not Italic, Word underline \\
\hline Formatted: Font: Not Italic, Word underline \\
\hline Formatted: Font: Not Italic, Word underline \\
\hline Formatted: Font: Not Italic, Word underline \\
\hline Formatted: Font: Not Italic, Word underline \\
\hline Formatted: Font: Not Italic, Word underline \\
\hline Formatted: Font: Not Italic, Word underline \\
\hline Formatted: Font: Not Italic, Word underline \\
\hline Formatted: Font: Not Italic, Word underline \\
\hline Formatted: Font: Not Italic, Word underline \\
\hline Formatted: Font: Not Italic, Word underline \\
\hline Formatted: Font: Not Italic, Word underline \\
\hline Formatted: Font: Not Italic, Word underline \\
\hline Formatted: Font: Not Italic, Word underline \\
\hline Formatted: Font: Not Italic, Word underline \\
\hline Formatted: Font: Not Italic, Word underline \\
\hline Formatted: Font: Not Italic, Word underline \\
\hline Formatted: Font: Not Italic, Word underline \\
\hline Formatted: Font: Not Italic, Word underline \\
\hline Formatted: Font: Not Italic, Word underline \\
\hline Formatted: Font: Not Italic, Word underline \\
\hline Formatted: Font: Not Italic, Word underline \\
\hline
\end{tabular}


notice was not "practicable” and an Odawa homestead could be lost without the owner ever knowing._-_Blackbird tried to intervene of Lucy Penaseway’s behalf._-_He got the Indian Agent to appeal to the Department of the Interior, yet while the matter worked its way through the bureaucracy, the "timber sharks" had the tract stripped of all its merchantable timber.-_Indian Agent George Lee could only complain that Penaseway’s shabby treatment was “as bad as the most heartless treatment of ex-slaves of the South.”-_In another case, two Odawa Civil War veterans lost their homestead claim because they did not have the funds to travel in the dead of winter with witnesses the seventy miles to the hearing. ${ }^{20}$

Nor did Indian allotments escape the "timber sharks" attention.-_Local government that had once been under Odawa control was turned into a tool for land seizures.-_The Odawa held land under a variety of tenure regimes.-_Some held allotments from which the federal trust period had expired.-_Others were private property owners of tracts purchased decades before with funds from the original 1836 land cession, while still others claimed land under the 1862 Homestead Act.__For all of these Indian citizens property tax rates soared as European_Americans occupied public office.-_Certainly the developing region had a growing need for road improvements and an expanded public education system.-_-Yet under the Odawa administration of the county the annual tax on eighty acres of unimproved forest land was only one dollar. Under the newcomers the fee jumped to $\$ 32.85$. The need to raise cash to pay this hefty fee pushed some Odawa to seek wage labor and others to abandon their allotments altogether. Margaret Boyd, Andrew Blackbird’s sister, complained to President Ulysses S. Grant that the steep assessments were designed solely to “take our Lands away from us poor Indians.”-_Boyd

\footnotetext{
${ }^{20}$ Andrew Blackbird to George W. Lee, Indian Agent, May 12, May 18 , May 21, 1877, National Archives, RG 75, Letters Received by the Michigan Superintendency, 1877_1879, Box 3; Bruce A. Rubenstein, "Justice Denied: An Analysis of American Indian_White Relations in Michigan, 1855_1889" (Ph.D. diss., Michigan State University, 1974), 118-20; John O. Shomin to George Lee, Jan. 4, 1877, National Archives, M-234, Roll 412, 0133.
} 
who had been educated at a Catholic convent school took the extraordinary step of making the "long and bitter journey” to appeal personally to the President.-_In Washington she met with the Commissioner of Indian Affairs and was briefly ushered into Grant's office before being quickly passed off to Julia Dent Grant._-_Boyd felt she failed in her mission but her visit and her brother's letters did prompt the government to dispatch a Department of the Interior investigator._-_Edwin J. Brooks of the General Land Office reviewed fifty-two cases at the Traverse City office.-_In the overwhelming majority of the cases he found the Odawa had been "grossly imposed upon.”21

Federal officials investigating the land frauds against the Odawa received little cooperation from local authorities._-_Instead, they encountered undisguised hostility toward the Odawa.--_The leading men of the community believed it was justifiable to "use very means possible” to “dispose them of their lands.”-_It was considered standard practice to snare Indians in debt through the sale of luxury items or the extension of credit at usury rates, to threaten property owners with violence, or simply to trick Indians into signing quit-claim deeds.-_Others waited and watched like wolves to pick_off the weak.-_One speculator pointed to an Indian land owner and told investigator Edwin Brooks he "will be hard up next winter then I can buy his land at my own figures.”-_These actions and the hostility they revealed deeply discourage Andrew Blackbird.__He had married an English woman and had mixed-blood children._-For years he worked as an interlocutor between whites and Indians.-_Yet he was shocked by the "great antipathy and prejudice” that was rampant "which makes us feel we have no country now which we might call our own.”-_He despaired when he was unable to successfully defend his brother’s farm from seizure or his sister from an outrageous law suit.-_Blackbird was barely able to hold

\footnotetext{
${ }^{21}$ Margaret Ogabejigokwe to President Grant, 7 January 1877, National Archives, RG 75, Letters Received, M-234, Roll 412, p.0469; S. E. Waite, Old Settlers of the Grand Traverse Region (Traverse City: S. E. Waite, 1918), p.51; Edwin Brooks to Commissioner Hayt, Jan. 44 January, 12 Jan. 12, tary 1878, National Archives, RG 75, Letters Received by the Office of Indian Affairs, M-234, Roll 413, p. 0054 .
} 
on to his allotment when a prominent land speculator attempted to file a cross claim on the property. Blackbird was left to fume about the "sharp Lawyer thieves” who ensured that in a local court “an Indian has no chance for justice.”22

Michigan Indian agents were ineffective in protecting Native American land from lumber company plunder.-_Indeed, several agents were active in profiting from the plunder. Even those who meant well and made an ethical effort were frustrated by the sheer size of the agency they supervised.-_The ten_-thousand or so Indians in Michigan lived in widely separated reserves across the northern portion of the state while the agency was headquartered in Detroit. Usually the agent visited each agency only once a year, otherwise they monitored developments through correspondence from the Indians.-_All too often they responded to complaints bureaucratically by passing the issue on to Washington and awaiting instructions.-_In 1888 the Anishinaabeg made an effort to have one of their own appointed as the agent.-_Two candidates were put forward.-_Reverend John Rix Robinson, an Odawa mixed-blood with experience on the Isabella Reserve, would have continued the Methodist Church’s lock on the office.-_Andrew J. Blackbird had twice been employed by the Office of Indian Affairs before, and he had the support of the local Women’s National Indian Association.-_Blackbird who seems to have had the inner track hoped to give "a good shaking to those robbers of the region.”-_The Michigan Congressional delegation was under considerable pressure caught between supporters of the Indians and the lumber interests. The latter found a way to relieve the burden.-_No agent was appointed, instead without even consulting the Office of Indian Affairs, Congress simply defunded the Michigan

\footnotetext{
22 Brooks to Hayt, Jan. 44 January, Jan. 12, 12 January 1878; Blackbird to Lee, Jan. 20, zo January 1879, National Archives, RG 75, Letters Received, Box 3; Blackbird to Lee, Letters Received, Box 4; Rubenstein, Justice Denied, p.121; Blackbird, History of the Ottawa and Chippewa ${ }_{4}$ p.44; Blackbird to Commissioner of Indian Affairs, Mar. 29 , Z9March1886, National Archives, RG 75, Correspondence of the BIA, 1880-1907, Box 298. Blackbird's sister, Margaret Boyd, was sued for several hundred dollars by a white resident of Harbor Springs, Michigan, who claimed he was gored by an ox she owned in spite of no witnesses and no evidence the ox was hers.
}

\begin{tabular}{|l|}
\hline Formatted: Font: Not Italic, Word underline \\
\hline Formatted: Font: Not Italic, Word underline \\
\hline Formatted: Font: Not Italic, Word underline \\
\hline Formatted: Font: Not Italic, Word underline \\
\hline Formatted: Font: Not Italic, Word underline \\
\hline Formatted: Font: Not Italic, Word underline \\
\hline Formatted: Font: Not Italic, Word underline \\
\hline Formatted: Font: Not Italic, Word underline \\
\hline Formatted: Font: Not Italic, Word underline \\
\hline Formatted: Font: Not Italic, Word underline \\
\hline Formatted: Font: Not Italic, Word underline \\
\hline Formatted: Font: Not Italic, Word underline \\
\hline Formatted: Font: Not Italic, Word underline \\
\hline
\end{tabular}


Agency.-_It was a bitter blow to educated Anishinaabeg like Blackbird who trusted that government could yet make things right. ${ }^{23}$

What happened to the Ojibwe and Odawa in Michigan was by no means unique.-_The Ojibwe in Wisconsin and the Anishinaabeg on the Canadian side of the border experienced a similar process.-_James T. Gregory, the federal Indian agent in northwestern Wisconsin, openly facilitated the logging of the Bad River reserve.-_That should not have surprised anyone since prior to his appointment he had been an employee of the Superior Lumber Company in Ashland, Wisconsin, and that his appoint was in response to vigorous lobbying by said company which then went on to mill most of the timber cut on the reservation.-_When complaints that the reservation was being plundered of its only valuable asset roused a Congressional investigation, Gregory argued that the rapid cutting of Ojibwe timber was a positive good because it sped the way for those people's “civilized improvement."-_What is striking in retrospect is the similarity of abuse that occurred across the entire broad sweep of the Great Lakes forests.-_Indeed the process of dispossession that occurred among Saginaw Ojibwe was eerily similar to what historian Melissa Meyer documented occurred at the Ojibwe White Earth Reservation in far northern Minnesota during the first two decades of the twentieth century.-_-Sadly the nearly half century of time between the Saginaw and White Earth tragedies had done nothing to enlighten Indian policy. ${ }^{24}$

\footnotetext{
${ }^{23}$ Karamanski, Blackbird's, Song, p.210--12.

${ }^{24}$ Edmund Jefferson Danziger ${ }_{-} \mathrm{Jr}_{{ }_{2},}$ Great Lakes, Indian,Accommodation, and, Resistance, During, the,Early, Reservation Years, 1850-1900 (Ann Arbor: University of Michigan Press, 2012), p.76-77; Danziger, The, Chippewas, of,Lake. Superior (Norman: University of Oklahoma Press, 1979), 102; "Robbing the Indians: Further Investigations of the Wisconsin Timber Thefts," Chicago, Tribune, 24 MarchMar. 24, 1888; United States Bureau of Indian Affairs, Annual Report of the Commissioner, of, Indian, Affairs, to, the, Secretary of, the, Interior, 1888 (Washington, D.C.: U.S. Government Printing Office, 1889), p-xl--xlviii; Melissa L. Meyer, The,White,Earth, Tragedy: Ethnicity,and Dispossession, at a, Minnesota, Anishinaabe, Reservation, 1889--1920, (Lincoln: University of Nebraska Press, 1994), p.137-_-169.
} 


\section{Lumber Frontier Colonialism in Perspective}

The logging frontier’s expansion into Anishinaabeg lands was facilitated by a broad

Formatted: Font: Not Italic, Word underline failure of both federal resource management and Indian policy.-_Across the Great Lakes and Upper Mississippi regions of the Midwest, the allotment policy was carried out with the expectation that Indians would use the land as agriculturalists.-_Save for isolated tracts, however, the forested lands of the region were not suited to subsistence agriculture.-_The experience of European $n$-American settlers in New England and parts of up-state New York should have been an example of how problematic it was to develop forest farms.-_The task of clearing timber was formidable, and it ensured that these lands were the most expensive to settle.-_When loggers cut timber on land, it was not really cleared as they inevitably left behind stumps, dense piles of branches, and thin tree tops that became a great fire hazard. All too often allotment tracts were on sandy, shallow soiled areas with stands of pine that could never pay as farms. When deciduous forest lands with deep black soil were claimed by Anishinaabeg, they were often managed for small-scale maple sugar production.-_Old growth forests of pine, cedar, and hardwoods gave the land it's most marketable value, but the Office of Indian Affairs made no provisions for helping Indians to manage large stands of valuable timber.-_The very process of subdividing reservations through severalty made it impossible to manage the exploitation of forests as a sustaining tribal resource.-_The opening of reservation lands to white purchase was an invitation for the "timber sharks" to feed.

The Menominee Indians in Wisconsin and the Ojibwe at Red Lake in Minnesota were unique in their ability to withstand pressure from both local lumbermen and the U.S. Congress to sell off the tribe's timber rights and subdivide their reservation.-_- The Menominee avoided this with the help of William T. Richardson, the agent at Green Bay. The Menominee set up their 
own Indian lumber camp and gradually cut and later milled the reservation lumber themselves and did so in a sustained way.-_The Red Lake band were only able to avoid allotment by surrendering four-fifths of their reservation.-_The ceded portion was quickly logged over, but the remaining Red Lake reservation was protected as a tribal estate and eventually selectively logged by tribally owned mills._-_The Menominee and Red Lake examples suggest the transformational role that could be played by conscientious Indian Agents and united, determined tribal leadership.-_In most of the region, however, this did not happen and instead there was a rapid cutting of first the best pine and later the hardwood timber, a process that took only a generation, followed by the gradual harvesting of the rest of the forest for cordwood or pulpwood which continued well into the twentieth century.-_Federal timber agents were no more able to protect trees on federal land than federal Indian agents were able to protect Anishinaabeg forest lands. A program of wasteful plunder was the result. With homesteads lost and allotments logged over the best the Anishinaabeg could expect from the logging frontier was occasional employment in lumber camps. ${ }^{25}$

In the wake of the logging frontier, the entire region tried to cope with a radically transformed forest ecology that took the creation of county, state, and national forests to gradually restore.-_Those forest reserves saw a return of a vast portion of the land in the region to government ownership.-_It is ironic that a policy based on weaning the Indians from collective to individual private property was replaced, beginning with the 1911 Weeks Act, with a federal policy in which government reassumed collective control of some of the very same lands.-_The

\footnotetext{
${ }^{25}$ Patricia K. Ourada, The.Menominee, Indians: A History (Norman: University of Oklahoma Press, 1979), p-146-47.; s See also Brian Hosmer, American, Indians, in, the, Marketplace: Persistence, and, Innovation, Among, the Menominees, and Metlakatlans, 1870-1920 (Lawrence: University of Kansas Press, 1999), p.36--63;-and-David M. Beck, The Struggle for Self-Determination: History, of the Menominee, Indians since, 1854 (Lincoln: University of Nebraska Press, 2007), p-1=-22; Anton Treuer, Warrior, Nation: A, History, of, the, Red ,Lake, , Ojibwe, (St. Paul: Minnesota Historical Society Press, 2015), p.109--117.
} 
ethic behind the public forest system was to manage timberlands for the common good.-_Within a single generation tribal communal ownership was decried as barbaric and replaced with private property which resulted in waste and ruin and had to be replaced by a new system of communal ownership.-_There was, however, a significant difference in this new land management regime. State and federal forests included a regulatory regime that controlled Indian access to the land especially hunting, fishing, and gathering activities.-_In the wake of the logging frontier, the Anishinaabeg faced greatly reduced opportunities to exercise traditional subsistence practices. ${ }^{26}$ Both the European Americans and indigenous people of the Great Lakes forest region were essentially caught in the colonial grip of urban America._Lumbermen, who successfully fought off government regulation of forest lands, trumpeted the power and rationality of the free market._-_Yet there was little that was fair or rational in the way the lumber market functioned. Financial capital based in Detroit, Milwaukee, but especially Chicago, controlled the harvesting of the natural capital represented in the forest.-_A dependable lumber market like Chicago, the largest in the world by 1870, was essential to turn "green gold” into bankable dollars.-_Most Great Lakes region logging companies had a partner based in Chicago or another major city to handle marketing and to arrange the annual financing of operations.-_Because Chicago drew logs from throughout the region, it was a buyer's market with prices set low.-_Yet lumbermen embraced the market there because their desperate need for cash brought them to where lumber could be sold fast and in large volume.- The urban market manipulated lumbermen in the region just as they manipulated Indian allotments to their advantage.-_ This type of unequal relationship

\footnotetext{
${ }^{26}$ There is a long history of Odawa and Chippewa resistance to state and federal fish and game regulations based upon their understanding of the rights secured by nineteenth century treaties. Those rights were the subject of a series of lawsuits in federal district court from the 1970s to the early twenty-first century. For more on this, see, Robert Doherty, Disputed,Waters: Native_Americans and Great_Lakes,Fishing (Lexington: University Press of KentuckyPress, 1990); and Larry Nesper, Walleve,War: The Struggle, For Ojibwe, Spearfishing and Treaty, Rights (Lincoln: University of Nebraska Press, 2002).
}

\begin{tabular}{|c|}
\hline Formatted: Font: Not Italic, Word underline \\
\hline Formatted: Font: Not Italic, Word underline \\
\hline Formatted: Font: Not Italic, Word underline \\
\hline Formatted: Font: Not Italic, Word underline \\
\hline Formatted: Font: Not Italic, Word underline \\
\hline Formatted: Font: Not Italic, Word underline \\
\hline Formatted: Font: Not Italic, Word underline \\
\hline Formatted: Font: Not Italic, Word underline \\
\hline Formatted: Font: Not Italic, Word underline \\
\hline Formatted: Font: Not Italic, Word underline \\
\hline Formatted: Font: Not Italic, Word underline \\
\hline Formatted: Font: Not Italic, Word underline \\
\hline Formatted: Font: Not Italic, Word underline \\
\hline Formatted: Font: Not Italic, Word underline \\
\hline Formatted: Font: Not Italic, Word underline \\
\hline Formatted: Font: Not Italic, Word underline \\
\hline Formatted: Font: Not Italic, Word underline \\
\hline Formatted: Font: Not Italic, Word underline \\
\hline Formatted: Font: Not Italic, Word underline \\
\hline Formatted: Font: Not Italic, Word underline \\
\hline Formatted: Font: Not Italic, Word underline \\
\hline Formatted: Font: Not Italic, Word underline \\
\hline Formatted: Font: Not Italic, Word underline \\
\hline Formatted: Font: Not Italic, Word underline \\
\hline Formatted: Font: Not Italic, Word underline \\
\hline Formatted: Font: Not Italic, Word underline \\
\hline Formatted: Font: Not Italic, Word underline \\
\hline Formatted: Font: Not Italic, Word underline \\
\hline Formatted: Font: Not Italic, Word underline \\
\hline Formatted: Font: Not Italic, Word underline \\
\hline Formatted: Font: Not Italic, Word underline \\
\hline Formatted: Font: Not Italic, Word underline \\
\hline Formatted: Font: Not Italic, Word underline \\
\hline Formatted: Font: Not Italic, Word underline \\
\hline Formatted: Font: Not Italic, Word underline \\
\hline Formatted: Font: Not Italic, Word underline \\
\hline
\end{tabular}


was at the core of colonial economics, as was the disparity in living standards that flowed from it. The rugged conditions of the lumber camp, saw mill, or homestead tract—white or Indian, were in stark contrast to the mansions enjoyed by lumber barons and commission merchants in the city.-_That inequality only increased over time as the lumber industry transformed the

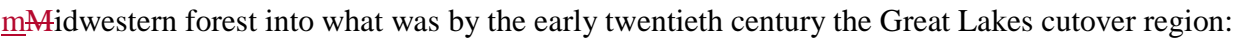
the devastated and denuded northern third of Michigan, Wisconsin, and Minnesota.- ${ }^{27}$

The colonialism of the logging frontier differed significantly from the settler colonialism that forced the removal of most of the indigenous people of the lower Midwest.-_Lumbermen were less interested in Indian land than they were in the resources that were on the land.-_Once timber was cut from land swindled from Indians, it was often abandoned by lumbermen and allowed to return to the state as a tax foreclosure or sold to poor farmers duped into thinking the cut-over had agricultural promise. The civil rights of citizenship and land ownership that leaders such as Mackadepenessy and Andrew Blackbird fought to achieve did not protect the Odawa and Ojibwe allotments from being plundered._-This sad state of affairs had been well_-documented by 1880 in the press and in the reports of federal officials.-_Nonetheless, in 1887 the alleged Friends of the American Indian pushed through Congress the General Allotment Act that would apply nearly same policy that failed in Michigan to Indians in Minnesota and in the western United States._-_Michigan had two decades of experience with allotment, Indian citizenship, and Indian land loss yet that example was willfully ignored.

The pine logging frontier was a white-capped wave that washed over the northern Great Lakes region in little more than a generation._-When it had crested, European_-American

\footnotetext{
${ }^{27}$ For a discussion of internal colonialism see- Pablo Gonzalez Casanova, "Internal Colonialism and National Development," _-Studies in Comparative,International_Development (1965) vol.1, no. 4, p. 27-37. For the economic organization of the Great Lakes lumber industry see William Cronon, Nature's, Metropolis: Chicago, and the Great West (New York: W. W. Norton \& Co., 1991),_p.148_-199.
}

\begin{tabular}{|c|}
\hline Formatted: Font: Not Italic, Word underline \\
\hline Formatted: Font: Not Italic, Word underline \\
\hline Formatted: Font: Not Italic, Word underline \\
\hline Formatted: Font: Not Italic, Word underline \\
\hline Formatted: Font: Not Italic, Word underline \\
\hline Formatted: Font: Not Italic, Word underline \\
\hline Formatted: Font: Not Italic, Word underline \\
\hline Formatted: Font: Not Italic, Word underline \\
\hline Formatted: Font: Not Italic, Word underline \\
\hline Formatted: Font: Not Italic, Word underline \\
\hline Formatted: Font: Not Italic, Word underline \\
\hline Formatted: Font: Not Italic, Word underline \\
\hline Formatted: Font: Not Italic, Word underline \\
\hline Formatted: Font: Not Italic, Word underline \\
\hline Formatted: Font: Not Italic, Word underline \\
\hline Formatted: Font: Not Italic, Word underline \\
\hline Formatted: Font: Not Italic, Word underline \\
\hline Formatted: Font: Not Italic, Word underline \\
\hline Formatted: Font: Not Italic, Word underline \\
\hline Formatted: Font: Not Italic, Word underline \\
\hline Formatted: Font: Not Italic, Word underline \\
\hline Formatted: Font: Not Italic, Word underline \\
\hline Formatted: Font: Not Italic, Word underline \\
\hline Formatted: Font: Not Italic, Word underline \\
\hline Formatted: Font: Not Italic, Word underline \\
\hline
\end{tabular}


settlement to some extent receded leaving ghost towns and shrunken, economically challenged communities in its wake.-_The Anishinaabeg remained._-_Catholic parishes and Methodist congregations and camp meetings helped to sustain a people left largely impoverished by the failure of federal Indian policy._-_Those core vessels of community remained useful tools of resistance that helped to sustain pride, tradition, education and in the twentieth century produced leaders who reestablished tribal sovereignty and an Indian role in determining how the resources of the region are managed.

Theodore J. Karamanski

Professer of History

Director, Public History Program

Loyola University Chicago
Formatted: Space After: 0 pt, Line spacing: Double

Formatted: Space After: $0 \mathrm{pt}$ 